\title{
THE EFFECT OF GARLIC ON CHOLESTEROL INDUCED HYPERLIPIDAEMIA IN RABBITS
}

\author{
Aftab Uddin Ahmed ${ }^{1}$, Syeda Farida Begum ${ }^{2}$, Humaira Naushaba ${ }^{3}$ \\ Md. Noor Islam ${ }^{4}$, Begum Shamsun Naher ${ }^{5}$ \\ ${ }^{1}$ Department of Anatomy, Ibrahim Medical College, Dhaka \\ ${ }^{2}$ Department of Gynae \& Obstetrics, Bangladesh Medical College, Dhaka \\ ${ }^{3}$ Department of Anatomy, Sir Salimullah Medical College, Dhaka \\ ${ }^{4}$ Department of Anatomy, Ibn Sina Medical College, Dhaka \\ ${ }^{5}$ Department of Anatomy, Sapporo Dental College, Dhaka
}

\begin{abstract}
An experimental biochemical study was made on rabbits to demonstrate the possible role of aqueous extract of garlic as an antilipidaemic agent in the prevention of hyperlipidaemia. Untreated rabbits on atherogenic diet showed worse lipidaemic status than the normal control ones, as evident in higher serum cholesterol, triglycerides (TG), low-density lipoprotein (LDL) and lower high-density lipoprotein (HDL) level. On the otherhand the rabbits on atherogenic diet treated with aqueous extract of garlic showed significantly better lipidaemic status. It is suggested that aqueous extract of garlic is an important determinant of serum lipid level, which is an antilipidaemic agent against the pathogenesis of atherosclerosis.
\end{abstract}

Ibrahim Med. Coll. J. 2007; 1(1): 16-20

\section{Introduction}

The population with relatively high levels of serum cholesterol have relative higher mortality from ischemic heart disease (IHD). Among the blood lipids, serum cholesterol has been shown to be consistently related to the rate of development of IHD. Elevated total cholesterol and low-density lipoprotein (LDL) are well established risk factors of atherogenesis ${ }^{1}$. On the other hand high serum level of high-density lipoprotein (HDL) maintain an inverse relation with risks. Coronary heart disease rarely occurs at total cholesterol levels below $160 \mathrm{mg} / \mathrm{dl}$ and that $220 \mathrm{mg} / \mathrm{dl}$ represents the cut-off value above which the coronary risk increases linearly ${ }^{2}$.

Simple fatty streak is the earliest lesion of atherosclerosis, which eventually change to fibrous plaques resulting in arterial occlusion, thereby producing overt clinical manifestations. With the possible exception of the early fatty streaks the reversal of atherosclerotic lesion does not occur even under most favourable conditions ${ }^{3}$.
Garlic, a widely distributed plant is used in all parts of the world, not only as a spice and a food, but also as a popular remedy for some common illness. Its importance was recognized several thousand years ago and was regarded as a remedy for a variety of ailments, including heart, diabetes and tumours ${ }^{5}$. As a natural product, garlic has become the focus for the promising protective effect against hyperlipidaemia and atherolscerosis ${ }^{6,7}$. However some authors have failed to confirm the effect of garlic on blood lipid and atherosclerosis in hyperlipoproteinaemic individuals ${ }^{8}$.

In view of this controversial effect of garlic on serum lipid, the present study was planned to re-evaluate the role of garlic in the prevention of hyperlipidaemia.

\section{Materials and Methods}

Eighteen healthy New Zealand white rabbits of either sex, weighing between 1 to $2 \mathrm{kgm}$ were selected for this study. The animals were kept on basal laboratory

Address for Correspondence:

Prof. Aftab Uddin Ahmed, Department of Anatomy, Ibrahim Medical College

122 Kazi Nazrul Islam Avenue, Shahbag, Dhaka-1000 
Ahmed AU et al

diet, with fresh food, water and in a good hygienic condition for 2 weeks before commencing the experiment to make adaptation with environment. The duration of the experiment was 10 weeks. The animals were divided into three batches of 6 depending on diet and drugs as follows.

1. Normal Control (6): On basal laboratory diet containing wheat and wheat brans ( $30 \%$ each), maize, Jill cake, kheshari (10\% each), soybean oil $4 \%$, molasses $1 \%$ with skimmed milk powder, vitamin mixtures and minerals in appropriate proportions. The diet was prepared according to the formula followed by the International center for Diarrhoeal Disease Research, Bangladesh (ICDDRB).

2. Atherosclerotic Control (6): On atherogenic diet containing basal laboratory diet $+6 \%$ coconut oil $+1 \%$ cholesterol. The atherogenic diet was prepared by dissolving powdered cholesterol in heated coconut oil. It was then mixed with pellets of basal laboratory diet and the mixture was agitated to have a homogenous distribution of cholesterol and coconut oil in the pellets.

3. Garlic treated (6): On atherogenic diet $+10 \mathrm{ml} / \mathrm{kg}$ freshly prepared aqueous extract of garlic daily. The bulbs of Garlic were sliced into pieces and homogenized with cold distilled water at a proportion of $1: 3$ by weight. The filtered mixture was centrifuged at $3000 \mathrm{rpm}$ for 15 minutes. The supernatant fluid was used for treating the rabbits. The procedure of preparation and the doses of aqueous extract of garlic were chosen from Augusti and Methew ${ }^{9}$.

To see the antilipidaemic effects of garlic, biochemical parameters were used. Serum cholesterol, triglycerides, low-density lipoprotein and high-density lipoprotein were estimated at the beginning and on the day of sacrifice for each animal of each batch. Comparative studies were made between the results among different batches of rabbits.

\section{Results}

After 8 weeks of atherogenic diet feeding, the rabbits developed small nodular skin lesions mostly in both ears. The initial lipid levels in different batches of rabbits were close to each other. At the end of the experiment, the serum lipid level of the cholesterol fed animals increased many folds to that of the initial levels except in the normal control batch (Table 1). Serum cholesterol level increased maximally to about 14 times the initial level and showed markedly higher level of cholesterol. The increase of serum triglycerides was relatively lower as compared to serum cholesterol and LDL level. The mean final serum HDL levels were less than the mean initial ones in all batches of rabbits.

\section{Serum cholesterol (Table 1)}

The mean final serum cholesterol level in the atheroscloretic control batch was 12 times more than that in the normal control ones. In the normal control rabbits the mean of the final serum cholesterol levels as percentage of the initial ones was $120.03 \pm 17.67 \mathrm{mg} / \mathrm{dl}$ and that of the atherosclerotic control ones was $1400.72 \pm 335.60 \mathrm{mg} / \mathrm{dl}$. A very significantly higher difference $(\mathrm{p}<.001)$ was found when the two batches of rabbits were compared statistically for the final serum cholesterol levels expressed as a percentage of the corresponding initial level.

The mean final serum cholesterol in the garlic treated rabbits was $496.94 \pm 261.48 \mathrm{mg} / \mathrm{dl}$, which was about 5 times higher than that of the corresponding mean initial level $(97.55 \pm 22.31 \mathrm{mg} / \mathrm{dl})$. The mean of the final levels expressed as percentages of the corresponding initial levels $(532.58 \pm 273.02 \mathrm{mg} / \mathrm{dl})$ was very significantly lower $(\mathrm{p}<.001)$ than that in the atherosclerotic control ones $(1400.72 \pm 335.60 \mathrm{mg} / \mathrm{dl})$.

\section{Serum triglycerides (Table 1)}

The mean final of serum triglycerides and that was expressed as percentage of the corresponding initial levels in the normal control batch was $131.44 \pm 30.29 \mathrm{mg} / \mathrm{dl}$ and $121.87 \pm 34.71 \mathrm{mg} / \mathrm{dl}$ respectively. The mean final serum triglycerides level in the atherosclerotic control batch was $328.30 \pm 58.93 \mathrm{mg} / \mathrm{dl}$, almost double than the mean final value in the normal control batch. The mean of the final triglycerides level expressed as percentages of the corresponding initial ones in this batch $(339.04 \pm 105.46 \mathrm{mg} / \mathrm{dl})$ was very significantly higher $(\mathrm{p}<.001)$ than that in the normal control ones.

The mean final level of serum triglycerides in the garlic treated rabbits was $177.06 \pm 69.46 \mathrm{mg} / \mathrm{dl}$ and the mean of the final levels expressed as percentages of the corresponding initial levels $(163.91 \pm 75.73 \mathrm{mg} / \mathrm{dl})$ was very significantly lower $(\mathrm{p}<.001)$ than that in the atherosclerotic control ones $(339.04 \pm 105.46 \mathrm{mg} / \mathrm{dl})$. 


\section{Low-density lipoprotein (Table 1)}

In normal control batch, the mean final serum level and the levels expressed as percentages of the corresponding initial levels was $66.11 \pm 25.81 \mathrm{mg} / \mathrm{dl}$ and $150.29 \pm 71.76 \mathrm{mg} / \mathrm{dl}$ respectively. The mean final serum LDL level in the atherosclerotic control batch $(1372.45 \pm 533.95 \mathrm{mg} / \mathrm{dl})$ was about 20 times than that of the mean final LDL level in the normal control ones $(66.11 \pm 25.81 \mathrm{mg} / \mathrm{dl})$. The mean of the final serum LDL levels expressed as percentages of the corresponding initial levels in this batch $(3201.15 \pm 700.37 \mathrm{mg} / \mathrm{dl})$ was very significantly higher $(\mathrm{p}<.001)$ than in the normal control batch $(150.29 \pm 71.76$ $\mathrm{mg} / \mathrm{dl})$. In the garlic treated batch, the mean final LDL level was $431.56 \pm 254.50 \mathrm{mg} / \mathrm{dl}$ and the mean of the final serum LDL levels expressed as percentages of the corresponding initial levels $(1862.63 \pm 1355.55 \mathrm{mg} /$ dl) was significantly lower $(\mathrm{p}<.05)$ than in the atherosclerotic control ones $(3201.15 \pm 700.37 \mathrm{mg} / \mathrm{dl})$.

\section{High-density lipoprotein (Table 1)}

The mean initial and final serum HDL levels in the normal control batch were $35.61 \pm 5.77 \mathrm{mg} / \mathrm{dl}$ and 34.24 $\pm 3.93 \mathrm{mg} / \mathrm{dl}$ respectively. The mean final HDL level in the atherosclerotic control batch $(23.17 \pm 4.01 \mathrm{mg} / \mathrm{dl})$ was about $30 \%$ lower than the mean final HDL level in the normal control ones $(34.24 \pm 3.93 \mathrm{mg} / \mathrm{dl})$. The mean of the final serum HDL levels expressed as percentages of the corresponding initial levels in this batch $(64.59 \pm$
$15.41 \mathrm{mg} / \mathrm{dl})$ was very significantly lower than $(\mathrm{p}<.001)$ then the normal control batch $(97.38 \pm 12.68 \mathrm{mg} / \mathrm{dl})$. In the garlic treated rabbits fed on atherogenic diet the mean final HDL level $(29.97 \pm 6.98 \mathrm{mg} / \mathrm{dl})$ and that the mean of the final serum HDL levels expressed as percentages of the corresponding initial levels in this batch $(92.36 \pm 15.89 \mathrm{mg} / \mathrm{dl})$ was significantly higher $(\mathrm{p}<.05)$ than that in the atherosclerotic control ones $(64.59 \pm 15.41 \mathrm{mg} / \mathrm{dl})$.

Statistical comparison of the final serum lipid (as percentage of the corresponding initial level) between different batches of rabbits were carried out through unpaired ' $t$ ' test of significance of difference.

\section{Discussion}

The effect of atherogenic diet when compared to the outcome of the basal laboratory diet feeding could be assessed by comparing the findings in the atherosclerotic control rabbits with those in the normal control ones. Statistically highly significant difference between the two batches of rabbits could be detected in all biochemical parameters. The mean final serum cholesterol as well as mean of the final levels expressed as percentages of the corresponding initial levels in the atherosclerotic control rabbits increased by about 10 times than that in the normal control ones. Bordia et al. ${ }^{6}$ and Sainani et al. ${ }^{10}$ reported about 8 times higher level of serum cholesterol in the

Table - I

Serum lipid levels in different batches of rabbits at the beginning and end of the experiment

\begin{tabular}{|c|c|c|c|c|}
\hline Batch & Serum lipids & $\begin{array}{l}\text { Serum lipid (mg/dl) } \\
\text { Initial }\end{array}$ & $\begin{array}{c}\text { Mean } \pm \text { SD } \\
\text { Final } \\
\end{array}$ & $\begin{array}{c}\text { Final serum lipid as a Percentage } \\
\text { of initial level(\%) Mean } \pm \text { SD }\end{array}$ \\
\hline 1. Normal control(n=6) & $\begin{array}{l}\text { Chol } \\
\text { TG } \\
\text { LDL } \\
\text { HDL }\end{array}$ & $\begin{array}{l}107.55 \pm 27.01 \\
109.63 \pm 16.48 \\
50.02 \pm 27.61 \\
35.61 \pm 5.77\end{array}$ & $\begin{array}{l}126.64 \pm 22.75 \\
131.44 \pm 30.29 \\
66.11 \pm 25.81 \\
34.24 \pm 3.93\end{array}$ & $\begin{array}{l}120.03 \pm 17.67 \\
121.87 \pm 34.71 \\
150.29 \pm 71.76 \\
97.38 \pm 12.68\end{array}$ \\
\hline 2. Ath control $(n=6)$ & $\begin{array}{l}\text { Chol } \\
\text { TG } \\
\text { LDL } \\
\text { HDL }\end{array}$ & $\begin{array}{l}102.30 \pm 19.48 \\
104.28 \pm 29.71 \\
45.05 \pm 21.81 \\
36.40 \pm 3.63\end{array}$ & $\begin{array}{l}1461.24 \pm 527.85 \\
328.30 \pm 58.93 \\
1372.45 \pm 533.95 \\
23.17 \pm 4.01\end{array}$ & $\begin{array}{l}1400.72 \pm 335.60 \\
339.04 \pm 105.46 \\
3201.15 \pm 700.37 \\
64.59 \pm 15.41\end{array}$ \\
\hline 3.Garlic treated $(n=6)$ & $\begin{array}{l}\text { Chol } \\
\text { TG } \\
\text { LDL } \\
\text { HDL }\end{array}$ & $\begin{array}{l}97.55 \pm 22.31 \\
109.68 \pm 11.98 \\
43.02 \pm 22.52 \\
32.60 \pm 5.96\end{array}$ & $\begin{array}{l}496.94 \pm 261.48 \\
177.06 \pm 69.46 \\
431.56 \pm 254.50 \\
29.97 \pm 6.98\end{array}$ & $\begin{array}{l}532.58 \pm 273.02 \\
163.91 \pm 75.73 \\
1482.63 \pm 1355.55 \\
92.36 \pm 15.89\end{array}$ \\
\hline
\end{tabular}

Batch 2 vs $1 \mathrm{p}<0.001$ for Chol, TG, LDL, HDL

Batch 2 vs 2 p $<0.001$ for Chol, TG, $p<0.05$ for LDL \& HDL 
Ahmed AU et al

atherosclerotic control batch than that in the normal control ones by feeding 0.5 gm of cholesterol to male albino rabbits for 8 and 12 weeks respectively. Hollander et.al. ${ }^{11}$ and Jain ${ }^{12}$ also demonstrated the same results. The final serum triglycerides and the mean of the final levels expressed as percentages of the corresponding initial levels were more than 2.5 times and about $65 \%$ respectively higher in the atherosclerotic control rabbits than that in the normal control ones. Similar higher levels have also been reported by Sainani et.al. ${ }^{10}$. The mean final serum LDL level in the atherosclerotic control rabbits increased by almost 20 times than that in the normal controls ones. Bordia et.al. ${ }^{6}$ Sannani et.al. ${ }^{10}$ studied on the male rabbits by feeding $0.5 \mathrm{gm}$ of cholesterol daily and found higher LDL level. The mean final serum HDL level in the atherosclerotic control rabbits was about $30 \%$ lower than that in the normal control ones. Similar reduction was reported by Sainani et.al. ${ }^{10}$ by feeding $0.5 \mathrm{gm}$ of cholesterol to rabbits for 12 weeks.

In the garlic treated rabbits, the mean final cholesterol level was decreased by $65 \%$ than that in the atherosclerotic controls ones. Jain ${ }^{12}$ (1976) and Sainani et.al. ${ }^{10}$ (1979) in the cholesterol fed rabbits treated with garlic for 12 weeks have reported similar reduction. $10 \%$ reduction of serum cholesterol after 3 hours in a healthy individual by simultaneous feeding of $50 \mathrm{gm}$ garlic juice with 100 butter and 4 pieces of bread have been observed by Bordia et al. ${ }^{4}$ Reduction of serum cholesterol has also been reported by Huq ${ }^{13}$ by intragastric administration of garlic in cholesterol fed rats for 10 weeks.

The mean final serum triglycerides level in the garlic treated rabbits was reduced by $45 \%$ than that in the atherosclerotic control rabbits. Bordia et al. ${ }^{6}$ and Sainani et al. ${ }^{10}$ also demonstrated similar results. Both found more reduction of serum triglycerides in the garlic treated rabbits. More than $25 \%$ reduction has been demonstrated by Zacharias et al. ${ }^{14}$ in sucrose fed atherogenic rabbits treated with $10 \mathrm{ml} / \mathrm{kg}$ of aqueous extract of garlic for 8 weeks.

The mean final serum LDL in the garlic treated rabbits was about $70 \%$ lower than that in the atherosclerotic control ones. Bordia et al. ${ }^{6}$ and Sainani et al. ${ }^{10}$ have observed about $20 \%$ reduction of serum of serum LDL level in a similar study. $40 \%$ reduction in the cholesterol fed rats treated with aqueous extract of garlic for 10 weeks was found by $\mathrm{Huq}^{13}$.
In the present study, the mean final serum HDL level in the garlic treated rabbits was increased by about $25 \%$ than that in the atherosclerotic control ones. Similar results were also reported by Bordia et al. ${ }^{6}$ and Sainani et al. ${ }^{10}$. Both observed quite higher levels of serum HDL in the cholesterol fed rabbits treated with garlic. Huq ${ }^{13}$ found serum HDL level increased by $30 \%$ in the garlic treated rats in comparison to rats fed on cholesterol diet only.

\section{Conclusion}

The untreated rabbits on atherogenic diet showed significantly worse lipidaemic status than the normal control ones as evident in higher serum cholesterol, triglycerides and LDL, with lower serum HDL level. On the other hand rabbits on atherogenic diet treated with garlic showed better lipidaemic status. This was apparent from significant difference between the two.

When there is a worldwide extensive search for effective, easily available and economically preventive agents against one of the deadliest killer disease-atherosclerosis, the present study has demonstrated that garlic may have an antilipidaemic role against the pathogenesis of atherosclerosis. Various authors have reported similar antilipidaemic property of garlic.

\section{Acknowledgment}

The authors are grateful to Dr. Khondaker Manzare Shamim, Professor \& Chairman, Department of Anatomy, Bangabandhu Sheikh Mujib Medical University, for his continuous support and valuable suggestions regarding this study.

\section{References}

1. Walsh JME, Grady D. Treatment of hyperlipidaemia in women. JAMA 1995; 274 14: 1152-57.

2. Assmann G. Lipid metabolism and atherosclerosis. Central Laboratory of the Medical Faculty, University of Munster and Institute for Arteriosclerosis Research at the University of Munster, Stutgart, New York: Schattauer, 1982.

3. St. Clair RW. Atherosclerosis regression in animal model : current concepts of cellular and biochemical mechanism. Prog Cardiovascular Dis 1983; 26: 109-28. 
4. Bordia A, Bansal HC, Arora SK, Rathore AS, Ranawat RVS, Singh SV. Effect of the essential oil (active principal) of garlic on serum cholesterol, plasma fibrinogen, whole blood coagulation time and fibrinolytic activity in alimentary lipaemia. J Assoc Phys Ind 1974; 22: 267-70.

5. Block E. The chemistry of garlic and onions .Sci Am 1985; 252: 94-99.

6. Bordia A, Verma SK, Khabia BL, Vyas A, Rathore AS, Bhu N, Bedi HR. The effective of active principle of garlic and onion on blood lipids and experimental atherosclerosis in rabbits and their comparison with clofibrate. J Assoc Phys Ind 1977b; 25: 509-12.

7. Bordia A, Verma SK. Garlic on the reversibility of experimental atherosclerosis.Ind Heart J 1978; 30: 47 50.

8. Arora RC, Arora S, Gupta RK. The long-term use of garlic in ischaemic heart disease: an appraisal. Atherosclerosis 1981; 40: 175-79.

9. Augusti KT, Mathew PT. Effect ofs long terms feeding of the aqueous extracts of onion and garlic on normal rats. Ind J Expt Biol 1973; 11: 239-41.
10. Sainani GS, Desai DB, Natu MN, Katrodia KM, Valame VP, Sainani PG. Onion, Garlic and experimental atherosclerosis. Jap Heart J 1979; 20(3): 351-57.

11. Hollander W, Kramsch DM, Franzblau C, Paddoch J, Colombo MA. Suppression of atheromatous fibrous plague formation by antiproliferative and antiinflammatory drugs. Circulation Res 1974; 34-35 (Supple 1): 131-39.

12. Jain RC. Onion and Garlic in experimental cholesterol induced atherosclerosis. Ind J Med Res 1976; 74 : 1504-14.

13. Haque MR. Effect of aqueous extract of garlic on serum and liver lipid profile of rats and its relevance to atherosclerosis (thesis). Dhaka: University of Dhaka, 1994.

14. Zacharias NT, Sebastian KL, Philip B, Augusti KT. Hypoglycaemic and hypolipidaemic effects of garlic in sucrose fed rabbits. Ind J Physio Pharmac 1980; 24(2): 151-53. 